\title{
The Power of the Picture, Poem, Prayer, and Person: Mythic Consciousness and Russian Sensibilities from the Icon and Pushkin, to Malevich and Mayakovsky
}

\author{
Mark Lipton
}

University of Guelph, Ontario, Canada

\begin{abstract}
Within Stalin's regime, elements of mythical idealism run parallel, though somewhat invisibly, to those of dialectical materialism in the modes of cultural production. It is especially difficult to pinpoint these elements, for they lie in a world opposed to the scientific and thus must be regarded in part as illusory. Yet this illusory spirit constantly marks Russia's history and therefore I chart a course into such domain to question the relationship between Russian spirituality and Russian creative expression in the period of the utopian dream. Susanne Langer in Feeling and Form describes \&amp;amp;amp;amp;amp;amp;amp;quot;mythic consciousness\&amp;amp;amp;amp;amp;amp;amp;quot; as the means of understanding the world in primitive phases of social development. From a Marxist-Stalinist perspective, as a shift from the primitive toward the cultured, idealism represented a continuation of the primitive. And as the shift toward Marxist ideology during the periods of great revolution was a movement away from the primitive, it marked a shift towards the perfection of discursive forms. Yet, through all this strife and shifting, a common element runs through all Russian/Soviet Literature and the Arts; regardless of era or art form, that difficult concept to define known as the Mysterious Russian Soul is what marks the greatness of Russia's contribution to Arts and the Humanities.
\end{abstract}

Keywords Russian Soviet Literature and the Arts, Soviet Identity, Pushkin, Mayakovsky, Malevich

"There is apparently nothing easier and actually nothing more difficult than to write about Russian literature" (Belinsky, 1956, p.9).

"We are prepared to destroy that which we have created because we believe more than any of them in the power of the picture, the poem, the prayer, of the person" (Towes, 2016, p. 291).

Let me begin with a prediction that I will later dismiss: Petersberg will soon rise as the new nation's capital.

Whether ideologically motivated, Russian 'social thought' leading to either dialectical materialism or transcendental idealism, the works I consider in this paper seek to unify a Russian sensibility whereby extreme notions are both doubled and duplicitous; the paradoxical approach to life and aesthetics-Russian double-binds, tortures Russian intellectual and aesthetic identities leading to or simply describing this unique and distinct manner of being in the

* Corresponding author:

liptonm@uoguelph.ca (Mark Lipton)

Published online at http://journal.sapub.org/arts

Copyright (C) 2019 The Author(s). Published by Scientific \& Academic Publishing

This work is licensed under the Creative Commons Attribution International

License (CC BY). http://creativecommons.org/licenses/by/4.0/ world. This double-bind is not nihilist in its formal sense; at first, nihilism seemed to be the most natural term linking Russian and Soviet works when materialism opposed idealism. In fact, on close inspection, what I discover are less the distinct elements of works according to the time period or school of thought and more the similarities which sketch a national sensibility emerging from the intense tensions and frictions of daily life.

This paper aims to connect the combustion of any kind of Russian national identity or sensibility to its towering attention and loving compassion of its literature and arts. I combine arts, here, including traditional icon painting and great Constructivist and Suprematist accomplishments in order to highlight the intersections of aesthetic values (opposed to literary forms), which direct my analysis away from political boundary lines, examining instead, what might be called Russia's "mythic consciousness." That is, those mythic symbols linked with linguistic and habitual (or ways of being in the world) elements of aestheticism that help identify and make tangible this towering sensibility.

For me, an understanding of Russian culture begins with the Russian symbol, the icon and the axe. It is the one cultural symbol that intrigued my sense of heritage; my mother's family is of Russian descent and as a child my prized possession was my grandfather's pin of an icon and an axe. I saw this pin as a cosmological symbol encompassing 
and enjoining the heights of heaven to the depths of hell. But these extreme fail as boundary lines, resisting my standard Aristotelian logic. As James Billington (1966) explains in interpretive history of Russian culture, these two artifacts do not illustrate the Russian "split between the saintly and the demonic . . . between holy pictures and unholy weapons. For icons have been used by charlatans and demagogues, and axes by saints and artists" (p. vii). Billington emphasizes this symbol as a site of irony as his history of Russian culture illustrates the many apparent oppositions which form a cultural through-line in Russia's history.

My argument aims to emphasize Billington's attention to ironic duality. Clearly, an ironic duality outlines the great schisms of Russian culture, whether between the icon and the axe; the theocratic and the fundamentalist; the east and the west; the aristocrat and the peasant; or the state and the intelligentsia. However, I accuse Billington of benevolence - perhaps, too much hope - in his descriptions of ironic duality because I read his understanding of irony as a supplication to the perplexities of Russia's history. Within the context of Russian history Billington's optimism brims with hope eternal:

"Irony is a hopeful, though not a reassuring concept. Man is not a helpless creature in a totally absurd world. $\mathrm{He}$ can do something about ironic situations, but only if he becomes aware of their paradoxical nature and avoids the temptation to conceal incongruities with complete explanations. The ironic view contends that history laughs at human pretensions without being hostile to human aspirations. It is capable of giving man hope without illusion." (p. 590)

In his survey of Russian cultural history, from the rise of Eastern Orthodoxy to Stalinism, irony is Billington's prayer for the future of Russia. He writes, "Life out of death, freedom out of tyranny-irony, paradox, perhaps too much to hope for" (p. 596). Moreover, Billington ignores much of the actual hostility of Russia's past; the weakness of Billington's history is its aversion to those displeasing facts which darken the glory of Russia. His failure to include such facts as Russian suffering, discrimination, and deaths in his interpretative history of Russia is itself an indictment of the author by his own terms. Irony conceals the incongruities of Russia's history.

Billington dismisses many of the oppositions with rear-view mirror logic. "History does make sense, though our understanding of it tends to come too late" (p. 590). He quotes Hegel's famous phrase, "The owl of Minerva spreads his wings only at the gathering of dusk" (p. 590), yet forgets Hegel's valuable earlier lessons. To glean this broader philosophical frame, I turn to Lewis Mumford (1944) descriptions of Hegel's lessons and relationship to Marx:

"His [Marx's] first master, Hegel, had taught him that the world as a whole was in a constant process of becoming; this was no aimless ebb and flow, but a purposeful current: it was the result of a struggle between opposites, in which a positive 'thesis' begot its negation or 'antithesis,' and in the course of the struggle created a higher unity or 'synthesis." (p. 200)

Rather than describing an ironic world, Hegel's perspective suggests a structuralist universe. It is, in fact, a metatheory regarding the construction of theories; insisting on the assumption that an object of study as a structure is valid; a world view which believes in the equal flow of the positive and the negative; and one which functions within the scientific paradigm which reflects Newton's laws of thermodynamics ${ }^{1}$. This structuralist perspective throws Billington's misuse of irony into relief due to his inability to see the constant struggle between opposites that plague Russia's history as rich examples of both the Hegelian quest for synthesis and the Newtonian order of the universe. With the metaphor of Minerva's owl, Billington implies irony onto oppositions like dialectical materialism and mystical idealism without seeing the paradoxical nature of such oppositions and without inscribing this nature, which resonates throughout the history of Russia, onto many of the sign-posts of cultural meaning which he describes as hopeful. Billington's thick description of events, though hopefully interpretative, continues to function as thoroughly detailing Russia's history. As a primary text of Russian cultural history, Billington's information is valuable even if his analysis of irony leaks.

Frequently irony is employed to edify and illustrate such contradictions, the irony of Hamlet's equivocation for example. However, irony cannot function as the sole element worthy of study or examination. I can identify irony in Shakespeare because that is how my ninth grade teacher made it accessible. But I was not as interested in the concept of irony as I was in the self-conscious dialectic that haunted poor Hamlet. "To die, to sleep; To sleep; perchance to dream; ay, there's the rub; For in that sleep of death what dreams may come" (p. 107). The irony of dead men's dreams can only be considered when the context of the Elizabethan World Order (and of a ghost!) is understood and accepted. Context is necessary to understand irony, but a paradoxical context often serves to illustrate the limits of our language and thought.

Anton Chekhov's (1860-1904) dramatic juxtaposition of laughter and despair, though a late example, illustrates the struggle between oppositions in Russian culture, and the necessity for such struggle to continue. Walter Kerr explains:

"He [Chekov] wrote comedies of the mind, comedies in which the most serious issues were reduced to absurdity by the malfunctioning of the instrument that ought to have been able to resolve the issues effectively. The failure of intelligence is his perpetual theme, the strait-jacketing of the intelligence by preconceived

1 Newton's laws contend; matter can be neither created nor destroyed; for every action there is an equal and opposite reaction; and that all things tend toward entropy. The notion of entropy supports the structuralist point of view, as entropy presupposes a system's structure by insisting on its diachronic development. 
attitudes his principal comic image." (p. 235)

Contradictions abound. Chekhov reflects the values of a Russian society that acknowledges the proverb: Better let die my neighbours' cow, than let me have my own. I was both struck and puzzled by such a world view that made no sense to my Western sensibility. That is, until I discovered the recent work by American novelist Amor Towles (2016) who captures this mythic consciousness of Russian duality. He writes,

"Do you know that back in the '30, when they announced the mandatory collectivization of farming, half our peasants slaughtered their own livestock rather than give them up to the cooperatives? Fourteen million head of cattle left to the buzzards and flies" (p. 290). This failure of intelligence, also a successful protest, has been difficult to capture in determining a Russian national sensibility. However, as I inspect Chekov further, I discover, for example, how The Cherry Orchard brims with contradictions which illustrate the Russian struggle between oppositions. Just as the old servant Feers, feared sick, is much loved, he is forgotten at the end of the play, his body soon to join his ancestors. And though the orchard is much valued, it cannot survive the strike of the axe, symbol of renewal. The unspoken stage directions resonate with the constant struggle in Russian culture.

"A distant sound that seems to come out of the sky, like a breaking harp, slowly and sadly dying away. Then all is silent, except for the sound of an axe striking a tree in the orchard far away." (p. 292)

The dying harp can only be juxtaposed with the sound of the axe because each of these represents the key elements of struggle in the Russian people. As the axe represent the renewal of the land, it symbolizes the material. The axe was the basic tool of Russia, all she needed to clear the cold land. Furthermore, Billington explains how the axe functioned as the principal weapon in both peasant uprisings and urban rebellions. "More than the rifles from the west and the daggers from the east, the axe of the north remained the court weapon of the Russian monarchy" (p. 27). As the axe suggests material control, it represents a renewal within the struggle between its converse: the idealism of spirituality. The symbolic connection made between the axe and the icon is not ironic. Icons or religious pictures are constant reminders of religious faith that offer a sense of security, faith, and purpose. Irony fails to adequately describe the symbolic relationship between the icon and the axe and its value to Russian peasants.

On casual examination, the cultural symbol of the icon and the axe connotes the union of spiritual exultation and material struggle. More than this, however, this rich sign-post of cultural meaning, with its conflicts between materialism and idealism, represents the conflicts and major oppositions in Russia's long cultural history. More than ironic, the paradox between the material and the ideal accurately describes the dynamic cultural symbols of Russia, their meanings, and their relationships to each other.
Whether such oppositions appear in painting, literature, politics, or people, an examination of Russia's history connotes these symbolic markers as a reciprocal equation. Like Zeno's paradoxes, these markers and cultural symbols are at first puzzling or absurd, yet turn out to be validly interpreted as logical.

Though the complicated relationship between the icon and the axe significantly illustrates the conflict between the materialism and idealism of the Russian people, it should be noted that such complexities are rooted further in a structuralist matrix of meaning. In other words, artifacts of cultural value will also demonstrate the same complexities, if not illustrate the deeper roots of this contradiction between the material and the ideal. As I move from my gradfather's pin - the icon and the axe-I look to another treasured object: my great-grandmother's icon painting of St. George and the dragon, which I was told hung in the corner of her family's front room. Let me emphasize the pre-eminence of the icon (that is, icon painting in general), in and of itself, as a rich descriptive marker of early Russian culture as representing this struggle within Russian identity.

"From the official endorsement of icon veneration at the second Council of Nicaea in 787 to the new iconoclasm of the Russian revolutionary tradition of the 1840 s, the cultural signification of spiritual and religious exaltation rested on the power of the icon. Each icon reminded man of God's continuing involvement in human affairs. Its truth could be immediately apprehended even by those incapable of reading or reflection. It offered not a message for thought but an illustration for reassurance of God's power in and over history for men who might otherwise have been completely mired in adversity and despair." (Billington, p. 35)

As an agency of meaning, an icon signifies Hegelian 'synthesis' with the struggle between God and the individual: its materials representing the manifest world yet the reception of its signifiers include the divine.

An icon expresses Russian cultural cosmology in miniature; its colours must be unmixed; the gold background is the light and grace of God; God as the background of all. The use of gold significantly directs economic attention towards the church; the cost of the consecrated; the material of the ideal. The icon has been called sacramental in that it is "the outward and visible sign of and inward and spiritual grace" (Cooper, 1987, p. 87). Closely linked to the icon is the uniquely Russian icon screen called the iconostasis. In the Eastern Orthodox Church, the iconostasis divides heaven and earth both vertically by the arch (heaven) and the sides and ground (earth) and horizontally by separating the chancel from the nave. The iconostasis, both as a point of reference and a site of meaning signifies the boundary between the divine and the human, the sacred and the profane. In addition, every tour of a Russian church briefly includes a description of the Russian cross: note the triple transom and the specific angle of the third cross. Both of 
these distinctive characteristics read semiotically as conflicts between the materialism and the idealism of Russian culture and serve as an agency of meaning across Russia which, I insist, has not been lost.

Russia swells with a welcoming sense of the spiritual that a visitor could receive no place else. I can only offer my experiences as a secular Jew, being drawn to visit the synagogue in St. Petersberg and afterward, proudly displaying my heritage with a star of David around my neck. This act was in part motivated by my desire to understand the curious phrase "The Mysterious Russian Soul" shared with me by many of my native hosts. As I inquired further, there seem to be two key phrases continuously used to describe the Russian people as inherently mysterious: as "wild beasts" and "humble people." As the former illustrates a material aspect of Russian consciousness, the latter depicts an ideal. The fusion of these two descriptive phrases illustrates the mythic world view encapsulated by the Russian duality of consciousness; a key characteristic of Russian sensibilities and mythic consciousness that explains much of Russia's turmoil. Russian mythic consciousness, here, reflects the national tendency towards the interdependence of art and religion, culture and politics. The icon illustrates clearly the almost paradoxical relationship between art and religion as the struggle between the material and the ideal.

Furthermore, the icon defies Billington's concept of irony as it illustrates a weakness in contemporary critical theory. Irony is perhaps the most characteristic mode of postmodernism, as it mocks established styles and expresses disbelief in the claims of established authority. As a formulist of fundamental philosophical popularism Michel Foucault (1973) argues that power actualizes and then resists its own power. The power of the icon however, actualizes without complete resistance, for though one may argue that the religious nature of the icon underwent a period of state appropriation, as Billington states, "the spell of the icon was never completely broken" (p. 36). As a symbolic form of cultural representation, the icon continues to foil the Foucauldian world view. For Foucault writes, “. . representation has lost the power to provide a foundation-with its own being, its own deployment and its power of doubling over on itself-for the links that can join its various elements together" (pp. 238-239). The power of the icon lies in its ability to structure Russian spirituality from a solid, historical base. This power and its connotations oppose irony by reflecting the crux of Russian contradiction between the material and ideal. As the icon represents both the nature of spirituality and the spiritual nature of the Russian people, few other cultural symbols are as rich in illustrating this unique quality of Russian aesthetic sensibilities. From my grandfather's pin to his treasured icon painting, these artifacts help focus Russian sensibilities and contradictory world views. This analysis situates my challenges at assessing Russian literary works; I now turn to Pushkin to consider my thesis further, regarding Russian sensibilities, aesthetic realms, and contradictory identities.

Alexander Sergeyevich Pushkin stands as one of the leading cultural figures in Russia's history, representing "the final flowering of eighteenth-century aristocratic aspiration" (Billington, p. 331). As with the power of the icon, Pushkin's poetry embodies the most significant element of Russian poetic power, subverting Foucaultian formula by continuing to serve as a key foundation upon which Russian creative expression is built. Certainly Pushkin was faced with political resistance in having to appease Tzar Nicholas. Perhaps there is no contest, some argue, when considering the impact of Russia's first revolutionary revolt -December 14, 1825, which gave shape to the Decemberists and the concept of Russia's intelligentsia. Boris Kagarlitsky (1988), historian of Russian and Soviet intellectuals, favours the cultural and ideological results of this uprising over its political outcomes when he writes: "With the Decemberists, the Russian intelligentsia finally crystallized, and the movement of political and social dissent associated with it would now become a permanent feature of imperial Russian history" (p.14). In contrasting Pushkin to the Decemberists, Billington calls Pushkin a "unpolemical writer, a man of shifting interests, tantalizing fragments, and elusive opinions" (p. 333). But, AvrahmYarmolinsky (1936), professor and translator of many Russian literary works, demonstrates Pushkin's forced resistance from autocracy and his subsequent sympathy with and admiration for the Decembrists' courage.

If James Billington describes Pushkin as a "supporter of autocracy in the 1820's" (p. 333), Avrahm Yarmolinsky contradicts this characterization as incomplete by including, for example, Pushkin's "Message to Siberia" (1827) in his collection:

"Deep in the Siberian mine,

Keep your patience proud;

The bitter toil shall not be lost,

The rebel thought unbowed.

The sister of misfortune,

Hope,

In the under-darkness dumb

Speaks joyful courage to your heart:

The day desired will come.

And love and friendship pour to you

Across the darkened doors,

Even as round your galley-beds

My free music pours.

The heavy-hanging chains will fall,

The walls will crumble at a word;

And Freedom greet you in the light,

And brothers give you back the sword." (pp. 62-63)

Pushkin is hardly the apolitical figure Billington describes on the strength of this piece alone. Given the role of political infusion in subsequent Russian culture, his enduring posthumous veneration would not be as significant if his work was devoid of these political themes. His message to those Decembrists in exile illustrate his deep humanity; though he was not a man of the masses, he had their emancipation at heart. In this sense, the figure of Pushkin 
seems to be self-contradictory; he was a friend of the Tzar, the gentry, the bourgeoisie, but an heir of all the ages, a precious part of Russian Soviet patrimony, shaping the literary language and fathering its literary expression. Pushkin appeals to all Russians, throughout the various political regimes, which are often described as oppositional to each other and have often been of a revolutionary and revisionist nature. To illustrate this enduring aspect of Pushkin's appeal Janko Lavrin (1947) cites the formidable nineteenth-century critic Vissarion Grigor'evich Belinsky (1811-1848):

"His [Pushkin's] existence continues in the consciousness of his readers. Each epoch, regardless of the rightness of its understanding, passes its own judgement on him, and at the same time leaves it to the next epoch to add something, without ever exhausting the whole truth about him." (p. 197)

The mythic meanings (and uses) of Pushkin reflect the national tendency towards the interdependence of art and religion, culture and politics. As the icon illustrates the almost paradoxical relationship between art and religion as resonating with the struggle between the material and the ideal, Pushkin's work illustrates an oppositional relationship between the cultural and the political. As the icon serves the Russian cross or the iconostasis as a symbol of the spiritual tradition of Russia, Pushkin's legacy serves all of Russian literature as a pivot of the nation's cultural tradition. And as Billington points out, "the real ancestor of the main line of Russian fiction" (p. 331) was Pushkin's Eugene Onegin with the characters Onegin and Tatiana as "the authentic Adam and Eve of the Mankind that inhabits Russian fiction" (p. 332). James Billington furthers his cultural analysis with "The Bronze Horseman" describing Pushkin as the generator of the Russian apocalyptic mentality.

"Drawing on his own memories of the flood in 1824, Pushkin transforms Falconet's bronze statue of Peter the Great into an ambiguous symbol of imperial majesty and inhuman power. The clerk Eugene, in whose final delirium the statue comes to life, became the model for the suffering little man of subsequent Russian fiction-pursued by natural and historical forces beyond his comprehension, let alone control." (p. 332)

If Pushkin's characters serve as great Russian literary archetypes evoking the duality of consciousness between cultural traditions and political practices, his use of language invokes the contradictory relationship that echoes the interdependent relationship between art and religion. Yarmolinsky describes Pushkin's chief medium of verse as singularly resisting translation, "since it is lacking in imagery and is innocent of intellection, relying for its magic on precision, clarity, and a verbal felicity as palpable as it is difficult to convey" (p. 11). It is not surprising then that various English translations of Pushkin's work illustrate this challenge.

Yarmolinsky's translator, Babette Deutsch, takes up this task and begins Pushkin's "The Prophet:"

"Athirst in spirit, through the gloom

Of an unpeopled waste I blundered,

And saw a six-winged seraph loom

Where the two pathways met and sundered." (p. 61)

Janko Lavrin in Pushkin and Russian Literature, though trusting Deutsch's translation on five accounts, employs a different translator, Walter Morison, to re-translate the same poem. The differences are subtle, but illustrate an attempt to capture the language's true essence. Morison renders "The Prophet" as following:

"With spiritual thirst aflame

Weary through empty wastes I wandered;

And lo, a six-winged seraph came

To meet me where the paths were sundered." (p. 69-71)

Though the differences between the two translations seem inconsequential, Morison replaces "Athirst in spirit" with "spiritual thirst"; "gloom of an unpeopled waste" with "empty wastes"; and "blundered" with "wandered," in an attempt to capture the essence of Pushkin's precise language. Morison's translation is less contrived, less pessimistic and as such, is the single Pushkin poem that avails a solemn biblical tone without sacrificing his dynamic restraint of it. This final point is emphasized at the end of the poem. In Deutsch's translation, God refers to himself twice, with the passages "my Will" and "my Word." In contrast, Morison transcribes the same passage with "My commands." I prefer Morison's translation because it more closely captures the idealism that runs throughout Pushkin's work. But Morison's language more precisely captures the spirit of Russian sensibilities that tend toward contradictory and paradoxical ideological forces - here, without irony. Further, this sensibility is contained, as Avrahm Yarmolinsky describes: "There is something in Pushkin's poetry, irrespective of its substance, as Tchaikovsky observed, which enables it to penetrate to the depths of the soul-that something is its music" (p. 11).

Interestingly, Billington illustrates conflict in Pushkin's work when he describes the influential theosophy (philosophy) of Professor Schelling in the 1830s and its influence on Nadezhdin, professor of art and archaeology at Moscow University and editor of Peter Chaadaev's "philosophical letters." Chaadaev was extremely critical of Russian materialism, calling Moscow the "Necropolis," and insisting that Russia "had so far been a part of geography rather than history, totally dependent on ideas and institutions imposed from without" (Billington, p. 315). In addition, Nadezhdin's theosophy is highly ideal as he "captivated his students by treating artifacts of past civilisations as occult symbols, finding the secret of the ages in an elegant piece of archaeology" (312). Billington explains that philosophy, "as the term came to be understood in the Nicholaevan era, was closer to the occult idea of 'divine wisdom' than to the understanding of philosophy as rational and analytical investigation in the manner of Descartes, Hume, or Kant" (p. 311). But, the point here, is 
that such pantheism commended itself to the Russian imagination prior to the revolution. As Billington explains, "Russians were thrilled by the appearance of a doctrine that purported to account for phenomena which they felt had been artificially excluded from the mechanistic world view of the eighteenth century" (p. 312). Such philosophy flourished in Pushkin's time. As a result, I look to Morison's translation because it more succinctly captures Pushkin's message and is closer to a language that reflects this pantheistic thinking. Pushkin's verse deliberately uses language to draw from his own contemporary cultural sensibility. But his control over language, to the point that his work is celebrated as cementing what defines Russian literary expression, frustrates this incorporeal ideology. Not surprising, Pushkin's language contains many of the same contradictory elements encountered in my previous analysis of the icon. Pushkin's language appealed to the ideal, from the material point of view.

"In his [Pushkin's] hands, Russian poetry came close to Nadezhdin's ideal synthesis of classical and romantic elements; the Russian language attained an elegance and precision that was at last devoid of affection; and the famous "broad Russian nature" was combined with the classical virtues of clarity and disciplined moderation." (Billington, p. 332)

Pushkin's use of language achieves this synthesis as it combines the classical, materialist organization of language with the idealized, romantic spirit.

In short, Pushkin, as an enduring cultural symbol, mirrors the complexity and paradoxical nature of Russian national sensibilities and identities. Both as a significant cultural figure and to wit, his work, signify the complex oppositions which resonate throughout the history of Russia and its national world views. Pushkin set the cultural foundations of Russian literature; politically, he served the dominant regime while simultaneously fuelling its opposition; and as an art form, his work reflects the contradictions of Russian sensibilities by using the material to invoke the ideal.

Not surprisingly, the most exciting elements of the ironic, paradoxical Russian sensibilities deeply penetrate the ideology of Marxism and the utopian dream dominated by the "three who made the revolution"-Lenin, Trotsky, and Stalin (Billington, p.459). Just as the icon and Pushkin embody the oppositional relationship between the material and the ideal, forms of creative expression of the utopian dream are caught between the same two extremes, though certainly to a lesser degree. The element of materialism is eminent in almost all forms of cultural production during this period, for if artistic achievement began to develop outside state jurisdiction, it was inevitably subverted and stifled. In other words, all forms of cultural production were to serve the needs of the state. However, the relational opposite to this seems very difficult to trace. The idealized element of these cultural artifacts, their relationship to the spirituality of the nation, and their subsequent forms seem readily apparent yet opposingly nihilistic. Yet they do exist and reflect a constant in the evolution of Russian/Soviet sensibilities and the Russian people: a duality of consciousness.

Within Stalin's regime, elements of mythical idealism run parallel, though somewhat invisibly, to those of dialectical materialism in the modes of cultural production. It is especially difficult to pinpoint these elements, for they lie in a world opposed to the scientific and thus must be regarded in part as illusory. Yet this illusory spirit invariably marks Russia's history and therefore I chart my course into such domain to question the relationship between Russian spirituality and Russian creative expression in the period of the utopian dream.

Susanne Langer (1953) in Feeling and Form describes "mythic consciousness" as the means of understanding the world in primitive phases of social development. She writes: "from earliest time, through the late tribal stages, men live in a world of 'Powers'--divine or semidivine Beings, whose wills determine the courses of cosmic and human events" ( $p$. 189). For Langer, the arts illustrate these powers and have done so in various ways: from a sacred bison or cow; to a Hermes or Apollo; and finally a Christ or God. From the occult and the mystical to the spiritual, the higher unity of idealism embodies the common elements which link this evolution. From a Marxist-Stalinist perspective, as a shift from the primitive toward the cultured, idealism represented a continuation of the primitive. And as the shift toward Marxist ideology during the periods of great revolution was a movement away from the primitive, it marked a shift towards the perfection of discursive forms. Langer describes non-discursive or presentational forms as possibly including the spiritual or mystical and thus lacking the rigor in structure of discursive forms. Yet Marxist ideology insists on logic and reason, rejecting former elements of idealism as leading to false ideas and values. A prophetic figure, cultural and literary critic Gyorgii Plekhanov (1912) explains:

"Mysticism is the implacable enemy of reason, but reason numbers among its enemies not only mystics but also those who advocate false ideas. When a work of art is based upon a fallacious idea, inherent contradictions inevitably cause degeneration of its aesthetic quality." (p. 91)

For Plekhanov, discursive forms characterize a Marxist ideology that more closely represents Hegelian synthesis. Consequently, Plekhanov directs art towards the structured and the reasoned. This is made explicit in Nicholas Bukharin's (1925) Art and Social Evolution when he writes: "The nature of art is now clear: it is a systematization of feelings in forms; the direct function of art in socializing, transferring, disseminating these feelings, in society..." (p. 101). Marxist tendencies insist on the structure of discursive forms and alienate presentational forms as mystical, forcing the latter to either adopt a discursive mandate or collapse.

In other words, the developing utopian dream in Soviet Russia insisted on the belief that symbol systems should be developed for utilitarian purposes, be they the dissemination and glorification of Marxism-Leninism, socialized 
transportation or education systems, and should include forms of creative expression. Yevegny Zamyatin's (1924) "OneState" in We or any Brave New World of your choice is full of rich examples. Presentational forms of expression were considered indices of an earlier, unperfected Russia and were silenced save the forms which could follow discursive logic. Marxist ideology insists on erasing any visions of mystical idealism to further a specific utilitarian purpose. Pushkin for example, could be studied within the more discursive paradigm of Russian Formalism. The Russian Formalists, who include Vikto Shklovsky, Roman Jakobson, Osip Brik, Yury Tynyanov, Boris Eichenbaum, and Boris Tomashevsky, "rejected the quasi-mystical symbolist doctrines which had influenced literary criticism before them, and in practical scientific spirit shifted attention to the material reality of the literary text itself" (Eagleton, 1983, p. 2 ). The literary text then becomes a material fact made of words rather than objects or feelings.

The ideal element here emerges from Langer's theory of "mythic consciousness" as the surviving element that runs through the history of Russian culture. Zamyatin articulates this common element, and promotes it as mythic, when he describes a poem and a prayer as the same thing.

"The Table--at this very minute, from the wall of my room, its purple figures on their golden ground are looking down at me sternly and tenderly, straight in the eyes. I can't help thinking of what the ancients called an "icon," and I feel like composing a poem or a prayer (which is the same thing). Oh, why am I not a poet, so that I might celebrate you properly, $\mathrm{O}$ Table, $\mathrm{O}$ heart and pulse of OneState!" (p. 12)

Zamyatin pinpoints the essential contradiction isolated in the cultural symbols of the icon and Pushkin. Though Langer insists that "scientific consciousness" replaces the mythic, as discursive forms of presentation and expression are perfected, she also argues that the shift between mythic and the scientific paradigm is never complete (p. 189). It is within this terrain of the incomplete shift between the mythic paradigm to the scientific paradigm that spirituality and the complexity of Russian sensibilities can be mapped.

The crux of Langer's argument begins by articulating the shift from the mystical to the scientific as never wholly possible, for the making of symbols cannot be totally practical and thus party political. In Philosophy in a New Key (1942) she describes three reasons why symbols did not evolve from the advantageous use of signs. For one, animals do not need speech to secure their basic need in fact, she describes how symbols can have more than one meaning, leading to mistakes and disagreements over interpretation. Second, she describes a serious attitude towards art and depicts artists as individuals ready to sacrifice wealth, comfort, and even health to follow their creative impulse. And third, she describes "the constant, ineffectual process of dreaming during sleep" to illustrate that we always make symbols: it is an innate, natural human characteristic (pp. 36-37). As a result, the Marxist drive towards discursive modes of cultural production will naturally contain such oppositional elements as "mythic consciousness." The Russian/Soviet national sensibility cannot be contained by any political or literary ideology. The complexity of daily life among Russians relies on ironic, paradoxical, and complex relations among human activity, symbolic work, and "mythic consciousness."

This complexity is also notably at work among Russian/Soviet visual artists. Camilla Grey (1962), art historian and critic, best known for her analysis of Russian "experiments in art 1863-1922" begins her monograph citing Nicolay Chernyshevsky (1828-1899). Chernyshevsky (1828-1899) a central figure in Russian radical thought and considered a spokesperson for Peredvizhniki or the "Wanderers" recognized literature and art as socially active forces, with the warrior cry, "Reality is superior to its imitation in art — which must not reflect, imagine or interpret, but really build - to prevent the accusation that art is an empty diversion to be despised" (Grey, p. 280). The rise of art as propaganda, mainly through Soviet realism, must continue to be juxtaposed against the Russian icon, where art is a function of spiritual activity. And following Langer's arguments, the Russian national symbolic drive accompanied by spiritual activity can never be lost entirely, as symbolic forms seek to resist imitation. Herein lies the paradoxes of Russian/Soviet art; the artist-priest to the artist-engineer; art for today versus art for tomorrow; art for elites or art for masses. As the intelligentsia reinforced these dichotomous world views, it cannot be emphasized enough, that "mythic consciousness" was still at work, as the cosmology of Russian thought lived among such object relations. The rise of art movements of the Constructivists and the Suprematists are what initially drew me into this rich and complex subject matter.

Kazimir Malevich's Black Square (early 1920s) has been described as "a work that marked the dawn of a new age in art" (Petrova, 1990, p. 6). Expressing this concept of the new, however, runs throughout all the forms of cultural production that essentially attempt to combat the power of the icon. The experimental premise of Grey's work is only flawed by her failure to acknowledge the influences of the portraiture of the eighteenth century. In "The New Portraiture," James Billington states that, "the old obraza, or 'forms,' through which God was thought to have intervened in history were replaced by persony or 'persons,' of importance who were thought to be making history in their own right" (before p. 200, plate VIII). Clearly, this theme of the new includes all acts of resistance to Langer's mythic consciousness. Despite various forms of resistance, all of this art yields to the icon's power of reflecting mythic consciousness.

Billington describes Kandinsky as a great influence on Russian Suprematism and Constructivism, and compares his work to the icon: "He sought not art for its own sake but 'the spiritual in art,' and sought to end idle spectatorism by re-creating the intimacy between man and art that existed in earlier religious art. His painting was based on pure line and 
color--the two primary ingredients of icon painting" (p. 517). If Kandinsky's work reflected the power of the icon, Malevich's work resumed the functions of this power. Billington describes Malevich's The Cow and the Violin, as a "kind of icon" (p. 477) for the pre-revolutionary artists. Malevich's ideal forms certainly satisfied the necessity of art to follow discursive forms, but his reflection of the revolution itself is not devoid of the mythic. Malevich describes his work as the representation of a real infinity, such a representation, though godless, is not without spiritual elements:

“... man's path lies through space. Suprematism is the semaphore of color. . The blue colour of clouds is overcome in the Suprematist system, is ruptured and enters white, as the true, real representation of infinity, and is therefore freed from the colored background of the sky." (Malevich in Billington, p. 485)

If Malevich's use of white depicts infinity, his balanced use of black renders the absolutist material world. Such oppositions, though new and revolutionary in form, reflect the mythic element in the Russian duality of consciousness. Malevich's use of white as infinity, especially as depicted in his Black Square, is not unlike the function of gold in 'the cosmology in miniature' of the icon. Also, on careful examination of Russian icon painting, it becomes evident that black in its pure form, was applied only in the pupil of the subject. Countless numbers of Russian icons exude spirituality, luring individuals into the painting through the pure black pupil as though light were being drawn into the retina. Malevich's Black Square reflects this impression, as Billington cites a description of Malevich as "a rocket sent by the human spirit into non-existence" (p. 485). In this sense, Malevich's position of non-existence mirrors the ideal existence of icon painting: as symbols, both are in a position to look out onto a changing social world, and as we look into these symbols, especially into the black of these symbols, we acquire a better understanding of that changing social world. Malevich's discursive form is not without elements of the ideal, containing the same opposition which dominated the icon. Like the icon, Malevich's work signifies the role and function of mythic consciousness as impacting the Russian sensibility toward the unending paradox between reality and imagination. Malevich's nod to interdependent relations between art and religion function as unifying characteristics of this Russian sensibility or what I have come to recognize as the mysterious "Russian Soul."

The mysterious nature of Russian identities and sensibilities are made complete in the utopian dream expressed in the poetry of Vladimir Mayakovsky (1893-1930). His work parallels that of Pushkin as both signifying interdependent relations between culture and politics. As Yevgeny Yevtushenko (1993) explains:

"He was himself the revolution, with all its power, its excesses, its epic vulgarity and even brutality, its errors and tragedies. Mayakovsky's revolutionary zeal is evident in that this great love-lyric poet committed his verse to the service of ideological limericks, to the advertising billboards of politics." (p. 240).

As a result, it is not difficult to see why Mayakovsky was canonized by Stalin. Perhaps his epic "The Cloud in Trousers," illustrates how Mayakovsky bolstered the utopian dream.

\section{"Softies!}

You place your love on violins.

Crude folk like me place their loves on drums.

But you are incapable of turning thing around till all they form are lovers' lips."

(in Yevtushenko, p. 249)

The sound of the drum contains a greater revolutionary spirit for Mayakovsky, revealing his enduring love and revolutionary strength. Like the hegemonic powers behind Pushkin, Mayakovsky's work supported the state. As Stalin described: "Mayakovsky was and remains the best and most talented poet of our time. Indifference to his poetry is a crime" (in Yevtushenko, p. 240).

As Mayakovsky's role as a cultural figure is constantly consecrated by contemporary politics, he also reflects the often tense and complicated relationship between art and religion. In his work we can recognize elements of Langer's "mythic consciousness". For example, is it not with a little remorse that Mayakovsky describes the Cathedral of Vasily the Blessed on Red Square in Moscow after it suffered a shelling attack during the October Revolution in "Ode on the Revolution."

\section{"And tomorrow \\ Vasily the Blessed \\ will raise in vain \\ the cathedral rafters, begging for mercy, \\ the blunt-snouted hogs of your six-guns \\ will rake the Kremlin's millennia."}

(in Yevtushenko, p.263)

The power of the spiritual bemuses Mayakovsky, and much of his work reflects the values of a Christian redemption. Without irony, Billington describes his work as "Christian in form" and "mystical and semi-Oriental in content" (p. 516). Though Mayakovsky was calling for a more organic society in which all participated, he does so following Pushkin's classical tradition. His epic work, dedicated to the Russian Communist Party, "Vladimir Ilyich Lenin," is a clear example. It ends with classic crescendo:

\section{"Workers}

arise--

for the last fight resolved!

Straighten your backs--

Proletarian army, unbend your knees! there's no time to pause.

Long live Revolution, joyful and swift to be!

This is the greatest 
ever known

$$
\text { to history." }
$$

Like Pushkin's “Message to Siberia," Mayakovsky's view of the Revolution is heightened with romantic images yet abruptly succinct. Mayakovsky exemplifies the duality of consciousness between the material and the ideal, lending his work as an obvious example of utopian cultural production that appeals to the mysterious Russian soul and reveals the complex, often contradictory notions of Russian identities and sensibilities.

Both Mayakovsky and Malevich embody the fundamental contradictions which explain much of Russia's political, social, and cultural turmoil. Though these key figures of Russian arts support the materialism of the state, their work also appeals to the idealism of the people. This work identified and reflected upon the national tendency towards the interdependence of art and religion, culture and politics. Malevich, like the icon, and Mayakovsky, like Pushkin, illustrate the complex relations and duality of consciousness as a critical element from which Russia identity is unable to escape. As Dorothy had her red shoes, the cultural symbols of Russia both symbolize the inability to leave behind that which makes it whole.

the dead man dreams

Reflexes conditioned as culture popular, rethinking forecasts to The thinking reed. a place of sense a speak of art Occasions for Quotations and grammatical men with bible-philosophy applaud.

After the new criticism

Crucifixion -- muse of diction

Moscow becomes, in a nutshell,

Awake.

-- Moscow, 1996

\section{REFERENCES}

[1] Billington, J. (1966). The Icon and The Axe: An Interpretive History of Russian Culture. New York: Random House.

[2] Bukharin, N. I. (1925). "Art and Social Evolution" from Marxism and Art. (1972) Ed. by D. McKay.

[3] Chekhov, A. (1962). "The Cherry Orchard" in Four Modern Plays. Toronto: Holt, Rinehart and Winston.

[4] Cooper, J.C. (1979). An Illustrated Encyclopedia of Traditional Symbols. London: Thames and Hudson.

[5] Eagleton, T. (1983). Literary Theory: an Introduction. Minneapolis: University of Minnesota Press.

[6] Foucault, M. (1973). The Order of Things: An Archaeology of the Human Sciences. New York: Vintage Books.

[7] Grey, C. (1962). The Russian Experiment in Art 1863-1922. London: Thames and Hudson.

[8] Kerr, W. (1967). Tragedy and Comedy. New York: Simon and Schuster.

[9] Langer, S. (1953). Feeling and Form. New York: Charles Scribner's Sons.

[10] Langer, S. (1942). Philosophy in a New Key: A Study in the Symbolism of Reason, Rite and Art. London: Harvard University Press.

[11] Lavrin, J. (1947). Pushkin and Russian Literature. London: Hodder and Stroughton Limited.

[12] Mumford, L. (1944). Interpretations and Forecasts: 1922-1972. New York: Harcourt Brace Jovanovich.

[13] Petrova, E. (1990). "Introduction" to Malevich: Artist and Theoretician. Paris: Flammarion.

[14] Plekhanov, G. (1912). "On Art for Art's Sake” from Marxism and Art. (1972) Ed. by D. McKay.

[15] Shakespeare, W. "Hamlet" from The Falcon Shakespeare: Hamlet. (1963) Ed. by Betty Bealey.

[16] Towles, A. (2016). A Gentleman in Moscow. New York: Penguin Books.

[17] Yarmolinsky, A. (1936). The Works of Alexander Pushkin. New York: Random House.

[18] Yevtushenko, Y. Ed. (1993). 20th Century Russian Poetry: Silver and Steel. New York: Doubleday.

[19] Zamyatin, Y.I. (1924). We. United States of America: Dutton \& Co.. 